BLS 33, No 1 2007. DOI: http://dx.doi.org/10.3765/bls.v33i1.3540

(published by the Berkeley Linguistics Society and the Linguistic Society of America)

\title{
Reduplication in Indonesian and the Lexicalist Hypothesis
}

\author{
YOSUKE SATO \\ University of Arizona
}

\author{
BRADLEY MCDONNELL \\ Arizona State University
}

\section{Introduction}

In this paper, we discuss reduplication in Indonesian. We show that the corpus survey of four popular newspapers in Indonesia reveals that nominal reduplication allows both stem and stem-affix reduplication while verbal reduplication allows only stem affixation. This asymmetry in reduplication between nouns and verbs, as well as a word-internal reduplication pattern, poses a non-trivial architectural paradox for several versions of the so-called Lexicalist Hypothesis as in Chomsky 1970 and Kiparsky 1982a, b, and Mohanan 1986. We claim that this asymmetry crucially depends on morphosyntactic structures that underlie nominal and verbal reduplication within the recent non-lexicalist framework of Distributed Morphology (Halle and Marantz 1993, 1994, Harley and Noyer 1999, Embick and Noyer 2005).

\section{Reduplication in Indonesia and the Lexicalist Hypothesis}

To determine recurrent patterns in nominal and verbal reduplication in Indonesian, we have conducted a corpus survey of four popular newspapers in Indonesia. The result is shown in (1) below.

(1) The corpus survey of four popular newspapers in Indonesia

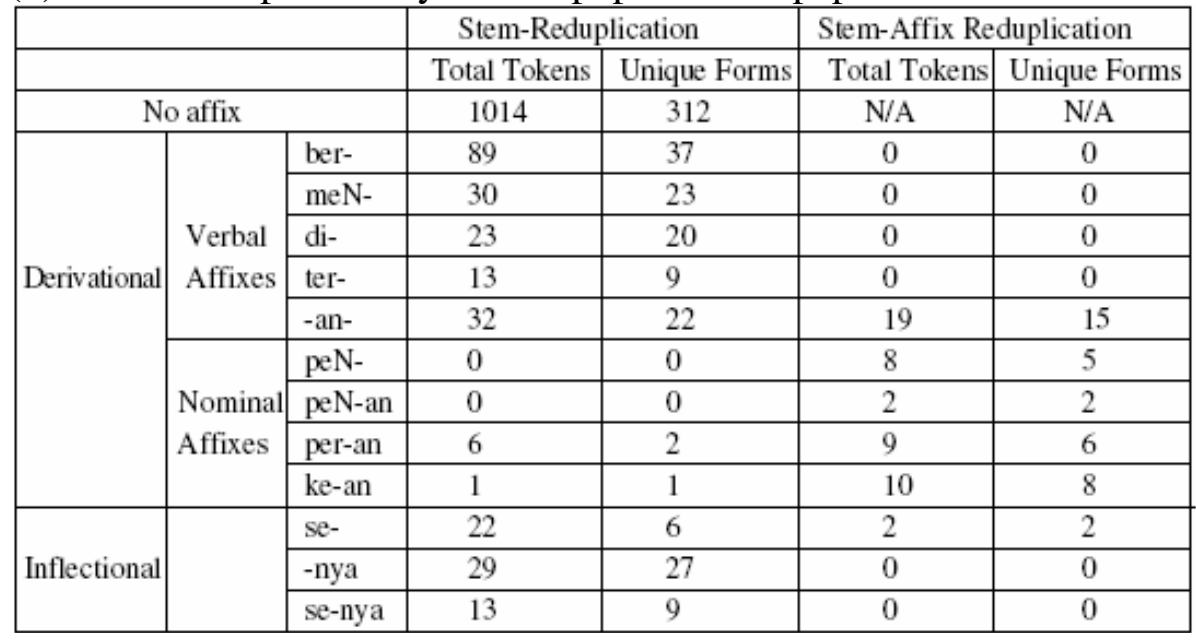


Yosuke Sato and Bradley McDonnell

This survey reveals a curious asymmetry that has never been reported in the literature. Whereas nominal reduplication allows both stem and stem-affix reduplication, verbal reduplication allows only stem reduplication. Given below are some examples that illustrate this asymmetry in reduplication.

$$
\begin{aligned}
& \text { Stem reduplication (verbs) }
\end{aligned}
$$

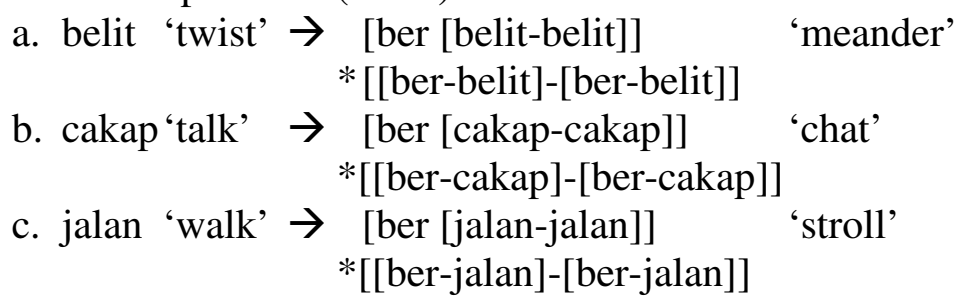

(3) Stem reduplication (nouns)
a. sayur-sayuran *sayuran-sayuran 'many types of vegetables' [[sayur-sayur]-an]] [[sayur-an]-[sayur-an]]
b. buah-buahan *buahan-buahan 'many types of fruits'
[[buah-buah]-an]] [[buah-an]-[buah-an]]
c. biji-bijian *bijian-bijian 'many types of seeds' [[biji-biji]-an]] [[biji-an]-[biji-an]]

(4) Stem-affix reduplication (nouns)
a. pikiran-pikiran [[pikir-an]-[pikir-an]]
b. tulisan-tulisan [[tulis-an]-[tulis-an]]
c. masukan-masukan
* pikir-pikiran 'thoughts' [[pikir]-[pikir]-an]] * tulis-tulisan [[tulis]-[tulis]-an]] [[masuk-an]-[masuk-an]] [[masuk]-[masuk]-an]]

Verbs allow only stem reduplication as shown in (2a-c). There are no instances that reduplicate a verb stem together with an affix. By contrast, the examples in (3a-c) and (4a-c) show that nouns allow both stem and stem-affix reduplication, depending on the nature of stems.

The existence of reduplication internal to words derived by affixation of ber- and -an in the data in (2-4) poses non-trivial difficulties for several versions of the so-called Lexicalist Hypothesis in the literature as in Chomsky 1970 and Kiparsky 1982a, b, 1985, and Mohanan 1986. Chomsky 1970 (see also Aronoff 1976) proposes that nonproductive, irregular processes such as derived nominals should be in the lexical component while productive, regular processes such as gerunds in the syntactic component. In this sense, ber-/-an affixation is certainly a lexical process. The prefix ber-may attach to nominal, numeral and verbal bases that yield unpredictable semantic meanings such as possession, characterization, and way of living/profession and it occasionally works as a verbalizer of verb stems that usually do not occur alone or add the 


\section{Reduplication in Indonesian and the Lexicalist Hypothesis}

additional sense of repetition and randomness, depending on what stem it identifies with. The function of suffix -an also varies; when it attaches to verbal bases, it serves as nominalizer; when it attaches to nominal bases, it works as kind of classifier, meaning 'many types of'. On the other hand, reduplication in Indonesian is a fully productive process. Reduplication of any countable noun produces a grammatical form that is specifically plural. Reduplication of a verb adds a connotation of variety or multiplicity. This is in tandem with the general notion of plurality/emphasized quantity, a crosslinguistically attested effect of reduplication (Moravcsik 1978, Travis 1999). If this is correct, examples of stem reduplication in verbs and nouns as in (2a-c) and (3a-c) are problematic for Chomsky's 1970 weak lexicalist theory because their formation requires reduplication as syntactic process followed by affixation as a lexical process, and this ordering is impermissible under this theory that posits the lexicon as a pre-syntactic component. In fact, the stem-affix reduplication that his theory would predict to be the only grammatical form is ungrammatical, as shown in (2a-c) and (3a-c). Furthermore, his weak lexicalist theory does not seem to have much to say about why there is an asymmetry as revealed in (1) where nominal reduplication allows both stem and stem-affix reduplication but verbal reduplication only allows stem reduplication.

The word-internal reduplication pattern also refutes one well-known version of the strong lexicalist theory called Lexical Phonology (Kiparsky 1982a, b, 1985, Mohanan 1986). This theory maintains that morphology and phonology interact in tandem with each stratum governing operations with certain properties. Specifically, affixation and irregular inflection with irregular phonological and morphological consequences in Stratum 1 while regular inflection with transparent and productive consequences occurs in a later Stratum (3 in Kiparsky and 4 in Mohanan). According to this criterion, ber-prefixation and an-suffixation occur at Stratum 1 due to their unpredictable behaviors as we have confirmed earlier. Reduplication occurs at Stratum 3/4 because of its fully productive nature. One important theoretical assumption of Lexical Phonology is the use of the

Bracketing Erasure Convention. This convention deletes all brackets at the end of each stratum of word formation and thus has the effect of rendering access to the previously available internal structure of words opaque for operations in later cycles. This convention, thus, derives part of the Lexical Integrity Principle that syntactic processes cannot look into the morphological make up of the complex morphological words. Lexical Phonology, therefore, predicts that no productive inflectional processes should be found within a (complex) word that is derived by affixation in earlier strata. This prediction is clearly incorrect in Indonesian because the inflectional process of reduplication targets part of the word derived by affixes (stem reduplication), not the right or left edge of the whole complex morphological object (stem-affix reduplication), in examples like (2a-c) and (3ac). As in Chomsky's 1970 weak lexicalist theory, Lexical Phonology also does 
Yosuke Sato and Bradley McDonnell

not seem to provide us with any way to derive the asymmetry between nominal and verbal reduplication in a principled way.

In this section, we have discovered that the reduplication pattern systematically differs between nominal and verbal stems: the former allows both stem-affix and stem reduplication while the latter only allows stem reduplication. We have shown that this asymmetry, as well as reduplication with morphologically derived stems, poses difficulties for versions of the weak and strong lexicalist hypothesis as proposed in Chomsky 1970 and Lexical Phonology in Kiparsky 1982a, b, 1985, and Mohanan 1986. For this reason, we pursue a nonlexicalist analysis of these facts in the next section.

\section{A Non-Lexicalist Account of the Reduplication Asymmetry in Indonesian}

We claim that the noted asymmetry between nominal and verbal reduplication, as well as the word-internal reduplication pattern, receives a straightforward account within the recent morphosyntactic framework of Distributed Morphology (Halle and Marantz 1993, Harley and Noyer 1999, Embick and Noyer 2005). In what follows, we assume, in line with much recent work on reduplication, that reduplication consists in affixation of the reduplicative morpheme RED that triggers copying on a stem in its neighborhood (Marantz 1982, McCarthy and Prince 1986, 1993, 1995, Travis 1999).

Consider first verbal reduplication. As we have seen in section 2, verb stems allow stem-reduplication but never allow stem-affix reduplication. This pattern receives a straightforward account if verbal reduplication is some sort of inner aspect (Travis 1999) as in the morphosyntactic derivation shown in (5) for the example in (2a).

Morphosyntactic derivation of the stem-reduplication in (2a)

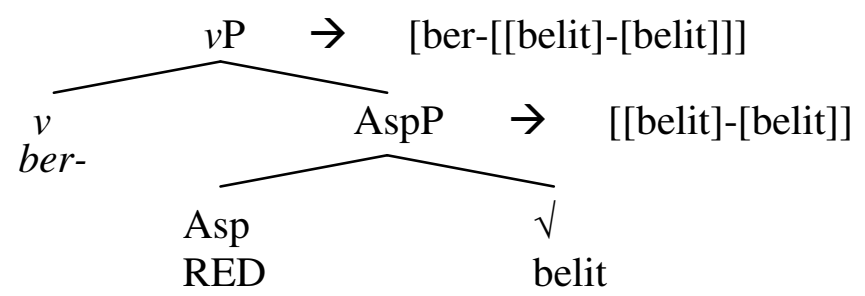

In this derivation, the Asp head merges with the root belit 'twist' as its complement. This object is spelled-out as the reduplicated form belit-belit. The AspP undergoes further merger with the verbalizing prefix ber- to derive the correct stem reduplication form ber-belit-belit 'meander'. The RED morpheme intervenes between the $v$ head and the root. Thus, the RED cannot reach up to the position of the $v$ to include the verbalizer ber- in its domain for reduplication. This accounts for the unavailability of stem-affix verbal reduplication. In this way, the fact that verb stems never reduplicate affixes naturally falls into place by assuming a particular hierarchical arrangement of certain morphosyntactic heads. 


\section{Reduplication in Indonesian and the Lexicalist Hypothesis}

Let us now consider nominal reduplication. As we have seen in section 2, nominal stems both allow stem and stem-affix reduplication. But this choice is not free but instead governed by the underlying syntactic category of a stem. Consider examples in (3a-c) and (4a-c), repeated here as (6a-c) and (7a-c), respectively.

$$
\begin{aligned}
& \text { Stem reduplication (nouns) }
\end{aligned}
$$

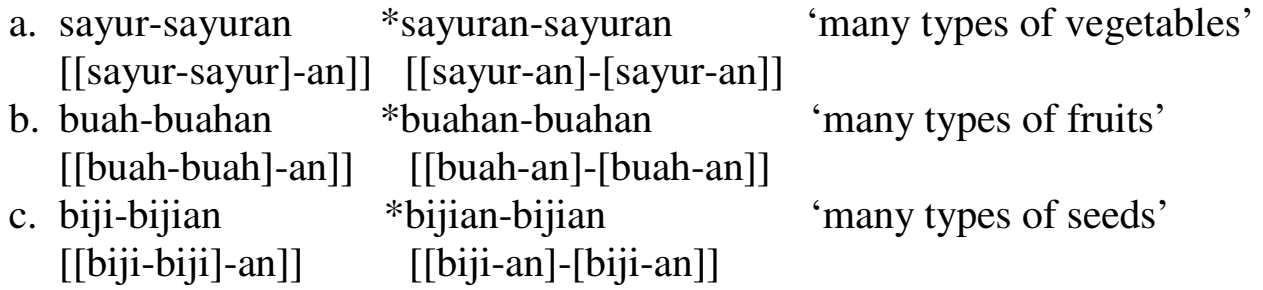

(7) Stem-affix reduplication (nouns)
a. pikiran-pikiran
* pikir-pikiran
'thoughts'
[[pikir-an]-[pikir-an]]
b. tulisan-tulisan [[pikir]-[pikir]-an]]
[[tulis-an]-[tulis-an]] [[tulis]-[tulis]-an]]
c. masukan-masukan
* masuk-masukan
'writings'
'inputs'
[[masuk-an]-[masuk-an]] [[masuk]-[masuk]-an]]

Specifically, input nominals in (6a-c) that allow only stem reduplication are all underived simplex nominals (sayur 'vegetable', buah 'fruit', and biji 'seed') whereas input nominals in (7a-c) that allow only stem-affix reduplication are all deverbal nominals (pikir 'think' $\rightarrow$ pikiran 'thought', tulis 'write' $\rightarrow$ tulisan 'writing', masuk $\rightarrow$ masukan 'input'). This difference, we claim, holds a key to a full understanding of why nominals allow two types of reduplication unlike verbs. Let us assume that nominal reduplication consists in the copying of a nominal stem by the RED in the Num head. The Num head selects a nominal stem as its complement, a reasonable assumption given that the reduplication of a noun yields an emphasized quantity of the referent of the noun (such as plural). Then, simplex underived nominal stems as in the examples in (6a-c) can undergo direct merge with the Num head. Verbal stems as in the examples in (7a-c), on the other hand, cannot merge with the Num head, which only takes a nominal stem as its complement. Thus, they are nominalized by the suffix -an in order to merge with the Num head. The derivations for the examples in (6a) and (7a), for example, are given in (8) and (9), respectively. 

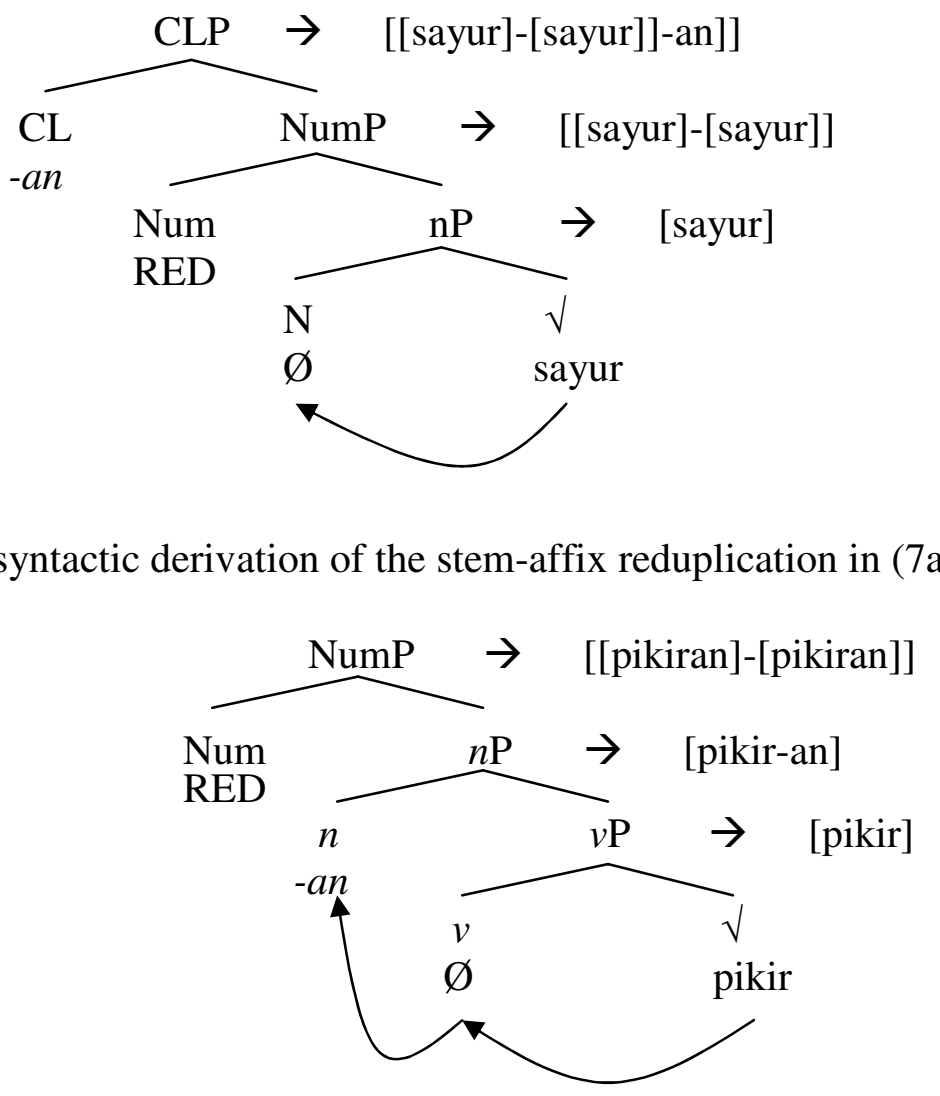

In the derivation in (8), the root sayur 'vegetable' is instantiated as a noun by movement into the $n$ head. This stem, being a nominal, can directly merge with the Num head as input for nominal reduplication. This derivation derives the stem-affix reduplication for simplex underived nominals as in (6a-c). The derivation in (9) is crucially different from that in (8), in that the base stems are all verbal. Accordingly, they are converted into nominal elements by the suffixation of -an to serve as correct complement to merge with the Num head. Since this head includes the nominalizing suffix -an in its structural domain, the RED is interpreted as reduplicating the verbal stem together with the suffix (pikiran). This derivation correctly yields the stem-affix reduplication for complex deverbal nominals as in (7a-c).

\footnotetext{
${ }^{1}$ The function of the suffix -an is certainly not a verbalizer as in the case of deverbal noun stemaffix reduplication. In the case of stem-noun reduplication, this suffix works as a kind of classifier in Bahasa Indonesia. Thus, buah-buahan, derived from buah 'fruit', means 'many types of fruits' but this suffix cannot be attached to stems like jeruk 'lemon' to derive jeruk-jerukan because the lemon is a specific instance of the fruit kind. The form jeruk-jerukan is not ungrammatical but means something different ('toy orange'). Thanks to Heidi Harley, Dwi Hesti Yuliani-Sato, and an audience at BLS 33 for raising this question and important discussion.
} 


\section{Reduplication in Indonesian and the Lexicalist Hypothesis}

\section{Conclusions}

The corpus study of four popular newspapers published in Indonesia shows that nominal stems allow both stem and stem-affix reduplication while verbal stems allow only stem reduplication and that both nominal and verbal stems may allow reduplication to target part of the morphologically derived word rather than the left/right edge of the word. These two facts pose non-trivial empirical difficulties for a few well-known versions of the so-called Lexicalist Hypothesis as in Chomsky 1970 and Kiparsky 1982a, b, 1985, and Mohanan 1986. This problem arises only when we adopt a theory that posits the generative lexicon as the presyntactic component. The inverse paradox required by word-reduplication in Indonesian ceases to be a problem under non-lexicalist theories because we do not have the lexicon in the first place. We have argued that the two facts above receive a straightforward account within the recent non-lexicalist, morphosyntactic framework of Distributed Morphology if we take into account a hierarchical arrangement of morphosyntactic heads such as Asp and Num as well as the underlying syntactic category of input stems for reduplication. The overall result, therefore, provides a strong piece of evidence against the general lexicalist theory, and, at the same time, argues in favor of non-lexicalist theories of the syntaxmorphology interface as in Distributed Morphology.

\section{References}

Aronoff, Mark. 1976. Word Formation in Generative Grammar. Cambridge, MA: MIT Press.

Chomsky, Noam. 1970. Remarks on Nominalizations. In Roderic Jacobs and Peter Rosenbaum, eds., Readings in English Transformational Grammar, 184221. Waltham, MA: Ginn.

Embick, David, and Rolf Noyer. 2005. Distributed Morphology and the Syntax/Morphology Interface. Ms., University of Pennsylvania. To appear in Gillian Ramchand and Charles Reiss, eds., The Oxford Handbook of Linguistic Interfaces. New York: Oxford University Press.

Halle, Morris, and Alec Marantz. 1993. Distributed Morphology and the Pieces of Inflection. In Kenneth Hale and Samuel Jay Keyser, eds., The View from Building 20: Essays in Linguistics in Honor of Sylvain Bromberger, 111-176. Cambridge, MA: MIT Press.

Halle, Morris, and Alec Marantz. 1994. Some Key Features of Distributed Morphology. Papers on Phonology and Morphology, MIT Working Papers in Linguistics 21:275-288.

Harley, Heidi, and Rolf Noyer. 1999. Distributed Morphology. Glot International 4:3-9.

Kiparsky, Paul. 1982a. Lexical Morphology and Phonology. In The Linguistic Society of Korea, ed., Linguistics in the Morning Calm, 3-91. Seoul: Hanshin. 
Yosuke Sato and Bradley McDonnell

Kiparsky, Paul. 1982b. From Cyclic Phonology to Lexical Phonology. In Hulst, H. van der and Norval Smith, eds., The Structure of Phonological Representations, 131-175. Dordrecht: Foris.

Kiparsky, Paul. 1985. Some Consequences of Lexical Phonology. In Kaisse, Ellen M. and Patricia A. Shaw, eds., Phonology Yearbook 2:83-138.

Marantz, Alec. 1982. Re reduplication. Linguistic Inquiry 13:435-482.

McCarthy, John, and Alan Prince. 1986. Prosodic Morphology. Ms., University of Massachusetts, Amherst, and Brandeis University, Waltham, Mass.

McCarthy, John, and Alan Prince. 1993. Prosodic Morphology I: Constraint Interaction and Satisfaction. Ms., University of Massachusetts, Amherst, MA; Rutgers University, New Brunswick, NJ.

McCarthy, John, and Alan Prince. 1995. Faithfulness and Reduplicative Identity. Papers in Optimality Theory, University of Massachusetts Occasional Papers in Linguistics 18:249-384. Amherst, MA: GLSA.

Mohanan, Karuvannur Puthanveettil. 1986. The Theory of Lexical Phonology. Dordrecht: Kluwer.

Moravcsik, Edith. 1978. Reduplicative Constructions. In Joseph H. Greenberg, ed., Universals of Human Languages. Vol. 3:297-334. Stanford, CA: Stanford University Press.

Sato, Yosuke. 2007. Derivational Morphology in Non-Lexicalist Theories: CrossLinguistic Evidence of Complex Phrase Structures within Morphological Words. Ms., University of Arizona, Tucson.

Travis, Lisa. 1999. A Syntactician's View of Reduplication. Proceedings of the Sixth Meeting of the Austronesian, Formal Linguistics Association Toronto Working Papers in Linguistics, 312-331.

Yosuke Sato

University of Arizona

Department of Linguistics

Douglass 200E

Tucson, AZ 85721-0028

yosukes@email.arizona.edu

Bradley McDonnell

Arizona State University

Department of English,

Language and Literature 350,

Tempe, AZ 85287

bradley.mcdonnell@asu.edu 